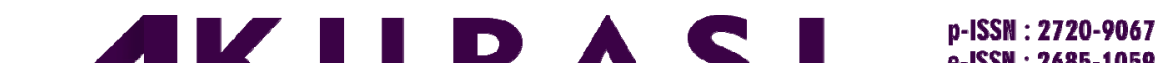 e-ISSH : 2685-1059 \\ Program Studi Magister Akuntansi \\ Fakultas Gkonorri dan Bisnis \\ Studl Akuntansl dan Keuangan \\ Universitas Mataram
}

\section{PENGARUH IMPLEMENTASI SIMDA DAN KINERJA APARATUR PEMERINTAH DAERAH TERHADAP KUALITAS LAPORAN KEUANGAN DIMEDIASI GOOD GOVERNMENT GOVERNANCE}

\author{
Rahmatia Azzindani ${ }^{1}$ dan M. Irwan ${ }^{2}$ \\ 1,2 \\ Program Studi Magister Akuntansi Universitas Mataram \\ Corresponding author : rahmatiaazzindani@gmail.com
}

\begin{tabular}{l}
\hline I N F O R M A S I A R T I KEL \\
\hline Article history: \\
Dikirim tanggal: $30 / 4 / 2020$ \\
Revisi pertama tanggal: $6 / 5 / 2020$ \\
Diterima tanggal: $27 / 5 / 2020$ \\
Tersedia online : $15 / 6 / 2020$
\end{tabular}

\section{A BST RAK}

Penelitian ini bertujuan menguji dan memberikan bukti empiris pengaruh implementasi Sistem Informasi Manajemen Daerah (SIMDA) dan kinerja Aparatur Pemerintah Daerah (APD) terhadap kualitas laporan keuangan dengan tata kelola pemerintahan yang baik (good government governance) sebagai variabel pemediasi. Penelitian dilakukan pada 32 Organisasi Perangkat Daerah (OPD) Pemerintah Kabupaten Lombok Tengah dengan responden sejumlah 96 yang terdiri dari pegawai subbagian keuangan dan akuntansi. Data dianalisis menggunakan path analysis, serta Intervening Regression Analysis (IRA) dan Sobel Test untuk uji mediasinya. Hasil penelitian menunjukkan bahwa implementasi SIMDA mempengaruhi kualitas laporan keuangan dan good government governance memediasi pengaruh kinerja aparatur pemerintah daerah terhadap kualitas laporan keuangan. Temuan lain penelitian ini mengungkapkan bahwa kinerja aparatur pemerintah daerah berpengaruh terhadap terwujudnya tata kelola pemerintahan yang baik, meskipun good government governance tidak memediasi hubungan implementasi SIMDA terhadap kualitas laporan keuangan pemerintah daerah.

Kata Kunci: implementasi SIMDA, kinerja aparatur pemerintah daerah, kualitas laporan keuangan, tata kelola pemerintahan yang baik

\begin{abstract}
The purpose of this study is to examine and provide empirical evidence of the influence of the implementation of Regional Management Information System (RMIS) and the performance of local government officials on the quality of financial reports with good government governance as a mediating variable. The study was conducted on 32 Regional Government Organizations of Central Lombok District Government with 96 respondents consisting of employees from the financial and accounting subsections. Data were analyzed using path analysis, as well as Intervening Regression Analysis (IRA) and Sobel Test for the mediation test. The results showed that RMIS implementation affects the quality of financial statements and good government governance mediates the effect of local government official's performance on the quality of financial statements. Other findings of this study reveal that the performance of local government officials influences the realization of good governance, although good government governance does not mediate the relationship of SIMDA implementation to the quality of local government financial report.
\end{abstract}

Keywords: implementation of Regional Management Information System, performance of local government official, financial reporting quality, good government governance 


\section{Pendahuluan}

Tuntutan masyarakat kepada pemerintah untuk menyelenggarakan pemerintahan yang baik merupakan hal yang wajar dan harus direspon oleh pemerintah dengan melakukan perubahan-perubahan yang mengarah pada terwujudnya penyelenggaraan pemerintahan yang baik atau yang dikenal sebagai good government governance (Sari, 2013). Good government governance atau tata kelola pemerintahan yang baik adalah suatu tatanan kehidupan berbangsa dan bernegara yang pola sikap dan tindak pelakunya dilandasi prinsip-prinsip dan karakteristik tertentu, sehingga good government governance berperan penting dalam meningkatkan iklim keterbukaan, partisipasi dan akuntabilitas sesuai dengan prinsip-prinsip dasar good governance pada sektor publik. Perubahan sistem politik, sosial, kemasyarakatan serta ekonomi yang dibawa oleh arus informasi telah menimbulkan tuntutan yang beragam terhadap good government governance (Yusniyar, dkk., 2016). Oleh karena itu, suatu penyelenggaraan pemerintah yang mengimplementasikan good government governance dapat diwujudkan, jika kinerja dari aparatur pemerintahnya baik dan dapat diandalkan (Dhiyavani, 2017).

Dalam suatu organisasi terutama organisasi pemerintahan diperlukan reformasi birokrasi terkait dengan upaya mencapai tujuan yang telah ditetapkan. Untuk mencapainya tidak bisa terlepas dari adanya unsur sumber daya manusia sebagai penggerak jalannya organisasi. Dengan demikian implementasi reformasi birokrasi pada organisasi pemerintahan membutuhkan sumber daya manusia yang berkualitas untuk dapat mencapai tujuan yang sudah ditentukan (Oktarina, dkk., 2016) dengan memiliki integritas dan kompetensi yang sesuai dengan tugas yang diembannya. Argumentasi tersebut mendukung studi Dhiyavani (2017) dan Yusniyar, dkk. (2016) yang menemukan bahwa kinerja aparatur pemerintah berpengaruh terhadap good government governance. Hal ini berarti bahwa jika aparatur pemerintah memiliki kinerja yang baik, maka pemerintah dapat mewujudkan good government governance guna memenuhi tuntutan dari masyarakat. Selanjutnya, dalam rangka mewujudkan good government governance baik dalam proses pengelolaan keuangan, penyajian laporan keuangan, serta akuntabilitas keuangan pemerintah, telah dikeluarkan peraturan perundang-undangan di bidang keuangan negara yang meliputi : Undang-Undang Nomor 17 Tahun 2003 tentang Keuangan Negara, Undang-Undang Nomor 1 Tahun 2004, dan Undang-Undang Nomor 15 Tahun 2004 tentang Pemeriksaan Pertanggungjawaban Keuangan Negara serta peraturan perundangundangan lainnya yang relevan. Hasil studi yang dilakukan oleh Sari (2013) menemukan bahwa kualitas laporan keuangan memiliki pengaruh terhadap penerapan prinsip good government governance, yang berarti bahwa untuk mewujudkan good government governance maka laporan keuangan yang dihasilkan pemerintah harus berkualitas dengan memperhatikan karakteristik yang menjadi tolak ukur dari laporan keuangan yang berkualitas, di antaranya: relevan, andal, dapat dibandingkan, dan dapat dipahami.

Tata cara pelaporan keuangan pemerintah yang dirasakan kurang transparan dan akuntabel telah berubah karena sebelumnya laporan keuangan tersebut belum sepenuhnya disusun mengikuti Standar Akuntansi Pemerintah (SAP) yang sejalan dengan standar akuntansi sektor publik yang diterima secara internasional (Ole, 2014). SAP merupakan persyaratan yang memiliki kekuatan hukum dalam upaya meningkatkan kualitas laporan keuangan pemerintah baik pemerintah pusat maupun pemerintah daerah di Indonesia 
(Oktarina, dkk. 2016). Dalam SAP dijelaskan bahwa laporan keuangan berkualitas itu harus memenuhi karakteristik berikut: relevan, andal, dapat dibandingkan, dan dapat dipahami. Laporan keuangan dapat dikatakan berkualitas apabila laporan keuangan yang disajikan setiap tahunnya mendapat penilaian berupa Opini dari Badan Pengawas Keuangan (BPK) (Azzindani, dkk. 2019). Untuk Laporan Keuangan Pemerintah Daerah (LKPD), laporan keuangan tersebut nantinya harus disampaikan oleh pemerintah daerah sebagai bentuk pertanggungjawaban pelaksanaan Anggaran Pendapatan dan Belanja Daerah (APBD) kepada Dewan Perwakilan Masyarakat Daerah (Oktarina, dkk. 2016).

Badan Pengawasan Keuangan dan Pembangunan (BPKP) merupakan auditor pemerintahan yang memiliki visi yang responsif, interaktif dan terpercaya untuk mewujudkan akuntabilitas keuangan Negara yang berkualitas dalam mentransformasikan manajemen pemerintahan menuju pemerintahan yang baik dan bersih serta sesuai amanat PP Nomor 60 Tahun 2008 pasal 59 ayat (2) dan Inpres Nomor 4 Tahun 2011. BPKP memandang perlu untuk memfasilitasi pemerintah daerah dalam mempersiapkan aparatnya menghadapi perubahan, mendorong pelaksanaan tata kelola keuangan daerah sesuai dengan peraturan yang berlaku, efisien, efektif, transparan, akuntabel dan auditabel, telah mengembangkan aplikasi komputer berupa Sistem Informasi Manajemen Daerah (SIMDA) (Ole, 2014). Implementasi SIMDA bertujuan sebagai sarana untuk pelaksanaan good government governance (BPKP, 2008). Berdasarkan data dari laman www.bpkp.go.id pada tahun 2017 terdapat sebanyak 542 pemerintah daerah telah mengimplementasikan SIMDA. Hal tersebut mengkonfirmasi hasil studi yang dilakukan oleh Pulungan (2014) yang menemukan bahwa implementasi SIMDA pada pemerintah daerah secara optimal dapat menghasilkan laporan keuangan yang berkualitas, baik dari sisi relevansi maupun keandalannya yang menjadi salah satu tolak ukur dari karakteristik kualitas laporan keuangan. Temuan tersebut sejalan dengan studi Sari (2013) yang menguji pengaruh sistem pengendalian intern pemerintah, implementasi SIMDA, dan penyelesaian temuan audit terhadap kualitas laporan keuangan pemerintah daerah di Provinsi Jawa Barat dan Banten dan implikasinya terhadap penerapan prinsip-prinsip tata kelola pemerintahan yang baik. Hasilnya menemukan bahwa sistem pengendalian intern pemerintah, implementasi SIMDA, dan penyelesaian temuan audit berpengaruh positif terhadap kualitas laporan keuangan pemerintah daerah. Sistem pengendalian intern pemerintah, penyelesaian temuan audit, dan kualitas laporan keuangan pemerintah daerah berpengaruh positif yang sangat lemah terhadap penerapan prinsip-prinsip good government governance, sedangkan implementasi SIMDA tidak berpengaruh terhadap penerapan prinsip-prinsip tata kelola pemerintahan yang baik.

Fenomena dalam penelitian ini didasari oleh informasi yang diperoleh dari survei lapangan pada Organisasi Perangkat Daerah (OPD) di Kabupaten Lombok Tengah. Pemerintah Kabupaten Lombok Tengah merupakan salah satu dari banyak kabupaten di Indonesia yang secara konsisten dapat mempertahankan opini Wajar Tanpa Pengecualian (WTP) dari Badan Pemeriksa Keuangan (BPK) selama lima tahun berturut-turut. Tabel 1 berikut ini menyajikan opini yang diperoleh Kabupaten Lombok Tengah dari tahun 2011 sampai dengan 2016 sebagaimana disajikan pada tabel 1 berikut ini: 
Tabel 1. Hasil Laporan Keuangan Pemerintah Kabupaten Lombok Tengah

\begin{tabular}{ccc}
\hline No & Tahun & Laporan Hasil Pemeriksaan dari BPK \\
\hline 1. & 2011 & Wajar Dengan Pengecualian \\
2. & 2012 & Wajar Tanpa Pengecualian \\
3. & 2013 & Wajar Tanpa Pengecualian \\
4. & 2014 & Wajar Tanpa Pengecualian \\
5. & 2015 & Wajar Tanpa Pengecualian \\
6. & 2016 & Wajar Tanpa Pengecualian \\
\hline
\end{tabular}

Berdasarkan tabel 1 tersebut di atas, maka dapat dinyatakan bahwa dengan diimplementasikannya SIMDA pada OPD Pemerintah Kabupaten Lombok Tengah memiliki dampak positif dalam kualitas laporan keuangan Pemerintah Kabupaten Lombok Tengah. Laporan Hasil Pemeriksaan (LHP) yang pada awalnya berstatus Wajar Dengan Pengecualian pada tahun 2011 menjadi Wajar Tanpa Pengecualian untuk pertama kalinya pada tahun 2012 hingga tahun 2016 (BPK RI Perwakilan NTB, 2017). Aplikasi SIMDA ini dikembangkan oleh BPKP guna membantu pengelolaan keuangan daerah di tingkat OPD sebagai entitas akuntansi. Adanya aplikasi ini diharapkan dapat memberikan manfaat lebih kepada pemerinah daerah dalam melaksanakan pengelolaan keuangan daerah. Akan tetapi, berdasarkan pengamatan awal yang dilakukan pada OPD Pemerintah Kabupaten Lombok Tengah ditemukan bahwa aplikasi SIMDA belum sepenuhnya digunakan secara optimal yang menyebabkan implementasi SIMDA oleh OPD belum dapat membantu mencapai tujuan organisasi pemerintah daerah secara maksimal. Hal ini diindikasikan karema kurangnya kesiapan OPD menerima dan mengaplikasikan software keuangan terintegrasi seperti SIMDA untuk melakukan prosedur akuntansi, serta belum adanya kepastian tentang software yang dijadikan standar dalam prosedur akuntansi sehingga menyebabkan masih beragamnya bentuk laporan keuangan yang dihasilkan oleh OPD. Hal tersebut jelas menyulitkan pengguna laporan keuangan tersebut dalam pengambilan keputusan. Selain itu, kemampuan penguasaan dalam pengoperasian SIMDA yang belum merata di setiap OPD, sedangkan software ini menurut penggunanya tidak hanya fasih dalam akuntansi tetapi juga dalam penggunaan komputer, serta masih banyak ditemukan pegawai OPD yang lebih memilih menggunakan aplikasi lainnya untuk menyelesaikan pekerjaannya yang dirasa lebih mudah daripada menggunakan aplikasi SIMDA.

Selain itu, OPD Pemerintah Kabupaten Lombok Tengah juga perlu memenuhi tuntutan masyarakat dalam menyelenggarakan tata kelola pemerintahan yang baik yang dapat dilakukan dengan cara melakukan pembangunan kualitas manusia dan meningkatkan kinerja aparatur pemerintah daerah sebagai pelaku good government governance. Dalam mewujudkan good government governance untuk tujuan menghasilkan laporan keuangan yang berkualitas dapat dilakukan dengan mengoptimalkan pengimplementasian SIMDA, sehingga penyusunan dan pelaporan keuangannya dapat disajikan dengan tepat waktu. Dengan demikian, peran good government governance sangat penting dalam membentuk dan meningkatkan kualitas laporan keuangan pemerintah daerah.

Studi sebelumnya yang mengelaborasi hubungan implementasi SIMDA dan kinerja aparatur pemerintah daerah terhadap kualitas laporan keuangan telah dilakukan dalam beberapa penelitian (Oktarina, dkk., 2016; Dhiyavani, 2017; Runtuwene, dkk., 2017; dan Azzindani, dkk., 2019). Secara spesifik penelitian ini menguji peran good government 
governance sebagai variabel intervening yang memediasi hubungan antara pengaruh implementasi SIMDA dan kinerja aparatur pemerintah daerah terhadap kualitas laporan keuangan. Dengan keberadaan good government governance diharapkan pemerintah daerah dapat meningkatkan efisiensi dan efektivitas pelaporan keuangan guna menghasilkan laporan keuangan yang berkualitas, sehingga kepercayaan publik semakin meningkat. Dengan implementasi SIMDA diharapkan dapat mengukur target atau sasaransasaran kinerja aparatur pemerintah daerah terutama dalam meningkatkan kinerjanya pada Organisasi Pemerintah Daerah. Hasil penelitian ini memberikan kontribusi tentang pentingnya keberadaan aparatur pemerintah daerah yang berkinerja baik dalam menunjang terwujudnya tata kelola pemerintahan yang baik, serta peran dari good government governance dalam mendorong terwujudnya laporan keuangan pemerintah daerah yang berkualitas.

\section{Kerangka Teoretis dan Pengembangan Hipotesis}

\subsection{Kajian Teori dan Telaah Riset Terdahulu}

Dengan adanya otonomi daerah yang merubah perilaku pemerintah untuk lebih efisien dan profesional, pemerintah daerah perlu melakukan perekayasaan ulang terhadap birokrasi yang selama ini dijalankan. Pemerintah yang memiliki peranan penting terhadap penetapan aturan-aturan, aspek dan mekanisme yang memiliki ketergantungan terhadap penggunaan sumber daya kepada seluruh masyarakat dengan adil dan merata (Dhiyavani, 2017). Tuntutan masyarakat kepada pemerintah untuk menyelenggarakan pemerintahan yang baik merupakan hal yang wajar dan harus direspon oleh pemerintah dengan melakukan perubahan-perubahan yang mengarah pada terwujudnya penyelenggaraan pemerintahan yang baik (Sari, 2013).

Suatu penyelenggaraan pemerintah yang mengimplementasikan good government governance dapat diwujudkan jika manajemen penyelenggaraan pemerintah atau kinerja aparatur pemerintah daerah yang baik dan andal meliputi manajemen yang kondusif, responsif dan adaptif (Dhiyavani, 2017). Peningkatan kinerja aparatur pemerintah daerah dapat dilihat melalui hubungan antara pengelola keuangan dengan atasannya, di mana pengelola keuangan merupakan orang yang diangkat atau dipilih oleh atasannya untuk melakukan tugas pengelolaan keuangan. Hubungan keagenan semakin terlihat pada saat seseorang yang telah diangkat atau dipilih untuk melaksanakan suatu tugas, bisa saja suatu saat dipromosi atau dinonaktifkan atau dimutasi ke bidang pekerjaan lainnya, sehingga menjadi suatu hal yang penting bagi para pengelola keuangan tersebut untuk terus meningkatkan kinerjanya guna memperoleh hasil yang baik atas pekerjaannya. Peningkatan kinerja dapat dilakukan dengan mengembangkan kompetensi melalui pendidikan, pelatihan, kursus dan pengalaman kerja.

Dalam rangka mewujudkan good government governance baik dalam proses pengelolaan keuangan, penyajian laporan keuangan, serta akuntabilitas keuangan pemerintah, telah dikeluarkan paket peraturan perundang-undangan di bidang keuangan negara yang meliputi: Undang-Undang Nomor 17 Tahun 2003 tentang Keuangan Negara, Undang-Undang Nomor 1 Tahun 2004 tentang Perbendaharaan Negara dan UndangUndang Nomor 15 Tahun 2004 tentang Pemeriksaan Pertanggungjawaban Keuangan Negara. Tata cara pelaporan keuangan pemerintah yang kurang transparan dan akuntabel 
telah berubah, karena sebelumnya laporan keuangan tersebut belum sepenuhnya disusun mengikuti SAP yang sejalan dengan standar akuntansi sektor publik yang diterima secara internasional (Ole, 2014). Hal tersebut juga didukung oleh studi yang dilakukan oleh Sari (2013), Oktarina, dkk. (2016), dan Yusniyar, dkk. (2016). Dalam rangka mengoptimalisasi manajemen daerah, saat ini BPKP telah mengembangkan aplikasi komputer berupa SIMDA (Ole, 2014) untuk membantu pemerintah daerah dalam penyusun laporan keuangan yang berkualitas guna mewujudkan good government governance. Organisasi Perangkat Daerah (OPD) Pemerintah Kabupaten Lombok Tengah sebagai stewards dipandang sebagai pihak yang dapat bertindak sebaik-baiknya bagi kepentingan principals dengan melaksanakan tugas dan fungsinya dengan tepat, sehingga good government governance dapat tercapai melalui aplikasi SIMDA yang dilakukan dengan pertimbangan faktor peralatan (tools) yang dilihat dari setiap alat atau software yang digunakan dalam pemanfaatan teknologi informasi. Dengan demikian, dapat dikatakan aplikasi SIMDA merupakan sistem yang terintegrasi secara menyeluruh dan mampu menghasilkan informasi yang handal dan relevan, sehingga mampu memberi output berupa laporan keuangan yang berkualitas. Hal tersebut didukung oleh studi yang dilakukan oleh Pulungan (2014) yang menemukan bahwa implementasi SIMDA berpengaruh positif terhadap good government governance. Hasil penelitian Azzindani, dkk (2019), Ole (2014) serta Kamal dan Noermansyah (2015) membuktikan bahwa implementasi SIMDA juga dapat mewujudkan laporan keuangan yang berkualitas.

\subsection{Pengembangan Hipotesis}

Dalam rangka mendukung good government governance pada penyelenggaraan otonomi daerah, pemerintah daerah perlu untuk diselenggarakan pengelolaan keuangan daerah secara professional, terbuka dan bertanggung jawab sesuai dengan aturan pokok yang telah ditetapkan dalam Undang-Undang. Undang-Undang Nomor 17 Tahun 2003 tentang Keuangan Negara dan Undang-Undang Nomor 1 Tahun 2004 tentang Perbendaharaan Negara yang mewajibkan pemerintah daerah dan OPD selaku pengguna anggaran untuk menyusun laporan keuangan sebagai bentuk pertanggungjawaban keuangan. Laporan keuangan berupa neraca, laporan arus kas, dan catatan atas keuangan harus disajikan sesuai Peraturan Pemerintah Nomor 24 Tahun 2005 tentang Standar Akuntansi Pemerintah. Hasil penelitian mengenai pengaruh implementasi SIMDA terhadap good government governance dilakukan oleh Dhiyavani (2017) yang menemukan bahwa pengimplementasian SIMDA sudah sangat baik dilakukan sehingga pemerintah daerah dapat mewujudkan good government governance guna memenuhi tuntutan masyarakat dalam hal transparansi atas laporan keuangan pemerintah daerah. Akan tetapi, hasil penelitian tersebut tidak sejalan dengan penelitian Sari (2013) yang menunjukkan bahwa implementasi SIMDA tidak memiliki pengaruh terhadap good government governance. Pemerintah daerah yang mampu mengimplementasikan SIMDA dengan baik dapat menciptakan tata kelola pemerintahan yang baik. Berdasarkan argumentasi tersebut maka diajukan hipotesis sebagai berikut:

$\mathrm{H}_{1}$ : Implementasi SIMDA berpengaruh terhadap good government governance.

Teori Penatalayanan mengargumentasikan bahwa pemerintah daerah dapat melaksanakan pengelolaan keuangan daerahnya secara terintegrasi, di mulai dari 
penganggaran, penatausahaan, hingga akuntansi dan pelaporannya. Pemerintah daerah tidaklah termotivasi oleh tujuan-tujuan individu tetapi lebih ditujukan pada sasaran hasil utama mereka untuk kepentingan organisasi pemerintahan, sehingga dalam mewujudkan kesejahteraan masyarakat dan mempertanggungjawabkan pengelolaan kekayaan negara untuk menghasilkan laporan keuangan yang berkualitas (Sari, 2013).

Pemerintah daerah memerlukan sistem yang dapat menghasilkan laporan keuangan dan informasi keuangan lainnya secara lebih komprehensif yang meliputi informasi mengenai posisi keuangan daerah, kondisi kinerja keuangan, dan akuntabilitas pemerintah daerah. Sistem tersebut juga harus mengacu pada Peraturan Pemerintah Nomor 58 Tahun 2005 tentang Pengelolaan Keuangan Daerah dan Peraturan Menteri Dalam Negeri Nomor 13 Tahun 2006 tentang Pedoman Pengelolaan Keuangan Daerah. SIMDA Keuangan merupakan salah satu aplikasi yang dikembangkan BPKP untuk optimalisasi manajemen daerah (Ole, 2014). Dengan diimplementasikannya SIMDA, laporan keuangan pada OPD Pemerintah Kabupaten Lombok Tengah memiliki dampak positif yang awalnya berstatus WDP pada tahun 2011 menjadi WTP pada tahun 2015 (BPK RI Perwakilan NTB, 2016). Studi Azzindani, dkk. (2019) pada kualitas LKPD Kabupaten Lombok Tengah menemukan bahwa implementasi SIMDA dan kinerja aparatur pemerintah daerah berpengaruh terhadap kualitas LKPD, sedangkan penerapan SAP tidak berpengaruh terhadap kualitas LKPD. Hasil studi tersebut sejalan dengan temuan penelitian Runtuwene, dkk. (2017), Kamal dan Noermansyah (2015), Pulungan (2014), dan Sari (2013) yang menemukan bahwa implementasi SIMDA berpengaruh terhadap kualitas laporan keuangan. Ketika pengimplementasian SIMDA pada pemerintah daerah meningkat dapat menghasilkan laporan keuangan yang berkualitas, sehingga diajukan hipotesis sebagai berikut :

$\mathrm{H}_{2}$ : Implementasi SIMDA berpengaruh terhadap kualitas laporan keuangan.

Berdasarkan argumentasi teori Penatalayanan, kewajiban pemerintah sebagai stewards adalah untuk memberikan pertanggungjawaban, menyajikan, melaporkan, dan mengungkapkan segala aktivitas dan kegiatan yang menjadi tanggungjawabnya dalam bentuk laporan keuangan kepada pihak principals yang memiliki hak dan kewenangan untuk meminta pertanggungjawaban tersebut. Pelaporan informasi tersebut sebagai bentuk pengukuran atas kinerja aparatur pemerintah dalam memberikan informasi yang dibutuhkan. Berkaitan dengan hal tersebut, OPD Pemerintah Kabupaten Lombok Tengah sebagai stewards dipandang sebagai pihak yang dapat bertindak sebaik-baiknya bagi kepentingan principals dengan melaksanakan tugas dan fungsinya dengan tepat, sehingga good government governance dapat tercapai melalui faktor manusia pelaksana (man) yang dapat mendorong pelaksanaan tata kelola pemerintahan yang baik.

Kinerja aparatur pemerintah adalah gambaran mengenai tingkat pencapaian pelaksanaan suatu kegiatan atau program atau kebijakan dalam mewujudkan sasaran, tujuan, misi dan visi organisasi dalam strategic planning suatu organisasi (Bastian, 2010:320). Reformasi birokrasi di Indonesia dilakukan untuk membangun aparatur negara yang mendukung keberhasilan pembangunan bidang lainnya. Keberhasilan reformasi birokrasi ditandai dengan adanya peningkatan kinerja aparatur karena pembangunan aparatur mampu meningkatkan kinerja pemerintahan secara keseluruhan. Kinerja pemerintah selalu terkait erat dengan perilaku kerja aparatur karena perilaku tersebut 
merupakan tindakan yang akan memengaruhi kegiatan yang dilakukan. Semakin baik kinerja aparatur pemerintah daerah, maka akan semakin baik good government governance yang diterapkan. Kinerja aparatur pemerintah yang baik, kondusif, responsif, dan adaptif dapat menghasilkan pembangunan kualitas SDM agar lebih berkinerja tinggi dan lebih produktif sebagai pelaku good government governance (Dhiyavani, 2017). Good government governance merupakan muara dari pelaksanaan otonomi daerah yang menghasilkan birokrasi yang andal dan profesional, efisien, produktif, serta memberikan pelayanan prima kepada masyarakat, sehingga kinerja dari aparatur pemerintah memengaruhi terselenggaranya good government governance yang menjadi isu sentral dalam pemerintahan. Studi yang relevan dilakukan Dhiyavani (2017) menemukan hasil bahwa kinerja aparatur pemerintah, pengelolaan keuangan daerah, dan implementasi SIMDA berpengaruh terhadap penerapan good government governance, akan tetapi sistem pengendalian internal tidak berpengaruh terhadap penerapan good government governance. Hasil yang sejalan didukung oleh studi Yusniyar, dkk. (2016) yang menemukan bahwa kinerja aparatur pemerintah daerah terhadap good government governance. Ketika kinerja aparatur pemerintah daerah meningkat, maka pemerintah daerah dapat memenuhi tuntutan masyarakat dalam mewujudkan good government governance. Berdasarkan argumentasi tersebut, maka diajukan hipotesis sebagai berikut:

$\mathrm{H}_{3}$ : Kinerja aparatur pemerintah daerah berpengaruh terhadap good government governance.

Argumentasi dalam Teori Keagenan digambarkan melalui hubungan antara pengelola keuangan dengan atasannya, di mana pengelola keuangan yang diangkat atau dipilih oleh atasannya untuk melakukan pengelolaan keuangan, bertanggung jawab untuk menyusun laporan pertanggung-jawaban keuangan dalam rangka akuntabilitas publik guna mewujudkan good government governance. Pengelola keuangan yang dipilih oleh atasannya artinya dipercaya mampu melaksanakan tugas yang telah diamanahkan, sehingga hal ini dapat menjadi ajang pembuktian bagi para pengelola keuangan tersebut bahwa mereka adalah orang yang tepat untuk melakukan pekerjaan tersebut dengan menghasilkan laporan keuangan yang berkualitas (Runtuwene, dkk., 2017).

Aparatur pemerintah daerah yang profesional dibutuhkan dalam rangka menjalankan tugas pokok dan fungsi pemerintahan secara tuntas. Dengan kompetensi yang dimilikinya, aparatur pemerintah daerah yang profesional akan dapat memenuhi standar target kinerja yang telah ditetapkan dan mampu menyusun laporan keuangan sesuai Standar Akuntansi Pemerintahan. Hasil penelitian yang dilakukan oleh Azzindani, dkk. (2019) yang menemukan bahwa kinerja aparatur pemerintah daerah berpengaruh terhadap kualitas laporan keuangan. Temuan tersebut didukung oleh penelitian-penelitian sebelumnya diantaranya Runtuwene, dkk. (2017), Oktarina, dkk. (2016), serta Ramadhan dan Rahayu (2015) yang menemukan bahwa pemerintah daerah telah mampu meningkatkan kinerja aparatur pemerintah guna menghasilkan laporan keuangan yang berkualitas. Keberadaan aparatur pemerintah daerah yang berkualitas akan mampu mendorong pencapaian laporan keuangan yang berkualitas. Berdasarkan argumentasi tersebut, maka diajukan hipotesis sebagai berikut:

$\mathrm{H}_{4}$ : Kinerja aparatur pemerintah daerah berpengaruh terhadap kualitas laporan keuangan. 
Dalam penerapan prinsip-prinsip good government governance, penyelenggaraan pemerintah daerah tidak terlepas dari masalah akuntabilitas dan tranparansi dalam pengelolaan keuangan daerah sebagai acuan untuk menghasilkan laporan keuangan pemerintah berkualitas (Sari, 2013). Secara konseptual pengertian good government governance mengandung dua pemahaman yaitu: nilai yang menjunjung tinggi keinginan atau kehendak masyarakat, dan nilai-nilai yang dapat meningkatkan kemampuan masyarakat dalam pencapaian tujuan kemandirian, pembangunan berkelanjutan dan keadilan sosial (Yusniyar, dkk., 2016). Kualitas laporan keuangan pemerintah daerah saat ini dan ke depannya ditentukan oleh kualitas tata kelola pemerintahan yang baik, dan inti dari kualitas pemerintah daerah sangat ditentukan oleh kualitas pengelolaan keuangannya (Sari, 2013). Dengan demikian, dalam rangka mewujudkan good government governance baik dalam proses pengelolaan keuangan, penyajian laporan keuangan, serta akuntabilitas keuangan pemerintah, telah dikeluarkan paket peraturan perundang-undangan di bidang keuangan negara yang meliputi: Undang-Undang Nomor 17 Tahun 2003 tentang Keuangan Negara, Undang-Undang Nomor 1 Tahun 2004, dan Undang-Undang Nomor 15 Tahun 2004 tentang Pemeriksaan Pertanggung-jawaban Keuangan Negara, selain dikeluarkannya paket peraturan perundang-undangan. Studi Oktarina, dkk. (2016) terkait pengaruh penerapan SAP, kinerja aparatur pemerintah dan good government governance terhadap kualitas laporan keuangan pada Dinas PKAD Kota Semarang menemukan hasil bahwa penerapan SAP, kinerja aparatur pemerintah, dan good government governance berpengaruh terhadap kualitas laporan keuangan. Temuan tersebut sejalan dengan hasil studi yang dilakukan oleh Yusniyar, dkk. (2016) yang mengungkapkan bahwa good government governance berpengaruh terhadap kualitas laporan keuangan. Ketika penerapan good government governance pada pemerintah daerah semakin baik, maka laporan keuangan pemerintah daerah akan semakin berkualitas. Berdasarkan argumentasi tersebut, maka diajukan hipotesis sebagai berikut:

$\mathrm{H}_{5}$ : Good government governance berpengaruh terhadap kualitas laporan keuangan.

Teori Penatalayanan mengargumentasikan pemahaman bahwa dalam pendekatan good goverment governance, untuk dapat menghasilkan informasi laporan keuangan yang berkualitas, maka sistem tata kelola pemerintahan yang baik harus memenuhi karakteristik kualitas informasi. Unsur dari karakteristik kualitas laporan keuangan seperti relevan dan reliabel harus terpenuhi dalam suatu laporan keuangan, sehingga laporan keuangan yang disajikan diyakini berkualitas dan dapat digunakan dalam pengambilan keputusan. Selain itu, peran good goverment governance terhadap kualitas laporan keuangan juga dapat dikaitkan dengan teori Keagenan yang digambarkan melalui hubungan antara pengelola keuangan dengan atasannya, baik bendahara pengeluaran maupun staf subbagian keuangan dan akuntansi pada OPD Pemerintah Kabupaten Lombok Tengah untuk melakukan tugas pengelolaan keuangan. Pengelola keuangan yang diangkat atau dipilih oleh atasannya bertanggung jawab untuk menyusun laporan pertanggungjawaban keuangan dalam rangka akuntabilitas publik guna mewujudkan good government governance.

Salah satu tujuan dari implementasi SIMDA adalah untuk menghasilkan laporan keuangan dan informasi keuangan secara tepat waktu, lengkap, akurat, dan dapat diandalkan sesuai ketentuan yang berlaku serta mendorong terwujudnya kepemerintahan 
yang baik pada umumnya dan penyelenggaraan pengelolaan keuangan daerah dengan menyediakan sistem pengelolaan keuangan daerah berbasis teknologi informasi pada khususnya (BPKP, 2008). Namun demikian, Pulungan (2014) mengidentifikasi beberapa hambatan yang ditemui pada implementasi SIMDA dalam penyusunan laporan keuangan yang dapat mengakibatkan kegagalan dalam penerapan aplikasinya, yaitu: kekurangpahaman para pemakai tentang komputer, kekurangpahaman para spesialis bidang informasi tentang bisnis dan peran manajemen, relatif mahalnya harga perangkat komputer, serta terlalu berambisinya para pengguna dalam membangun sistem informasi secara lengkap. Oleh karena itu, untuk memenuhi tuntutan masyarakat dalam mewujudkan good government governance, pemerintah daerah harus mengoptimalkan pengimplementasian SIMDA dalam penyusunan laporan keuangan agar laporan keuangan yang dihasilkan berkualitas. Secara tidak langsung, implementasi SIMDA dapat berpengaruh terhadap kualitas laporan keuangan (Runtuwene, dkk., 2017; Kamal dan Noermansyah, 2015; serta Pulungan, 2014) karena sebelum berpengaruh terhadap kualitas laporan keuangan, implementasi SIMDA akan terlebih memengaruhi good government governance (Dhiyavani, 2017; dan Sari, 2013). Dengan demikian, good government governance menjadi pemediasi hubungan antara implementasi SIMDA dan kualitas laporan keuangan. Dengan keberadaan good government governance, implementasi SIMDA akan mampu memengaruhi kualitas laporan keuangan. Berdasarkan argumentasi tersebut diajukan hipotesis sebagai berikut:

$\mathrm{H}_{6}$ : Implementasi SIMDA berpengaruh terhadap kualitas laporan keuangan melalui mediasi good government governance.

Seperti halnya implementasi SIMDA, kinerja aparatur pemerintah daerah juga dapat berpengaruh secara langsung maupun tidak langsung terhadap kualitas laporan keuangan. Pengaruh secara tidak langsung terjadi karena pada dasarnya kinerja aparatur pemerintah daerah akan berpengaruh terhadap good government governance (Dhiyavani, 2017; dan Yusniyar, dkk., 2016) dan selanjutnya kinerja aparatur pemerintah daerah akan berpengaruh juga terhadap kualitas laporan keuangan (Runtuwene, dkk., 2017; Oktarina, 2016; serta Ramadhan dan Rahayu, 2015). Dengan terwujudnya good government governance pada pemerintah daerah, maka akan menghasilkan laporan keuangan yang berkualitas sebagai bentuk pertanggungjawaban pemerintah daerah untuk menyajikan, melaporkan, serta mengungkapkan segala aktivitas dan kegiatan sebagai bentuk tanggungjawabnya kepada masyarakat (principals) yang memiliki hak dan kewenangan untuk meminta pertanggungjawaban tersebut.

Konsep good government governance harus dapat menerapkan suatu struktur atau proses yang menjamin adanya pengendalian dan pembagian kekuasaan yang seimbang untuk mengoptimalisasi tercapainya tujuan organisasi (Mardiasno, 2002:2017). Good government governance pada prinsipnya bertujuan untuk terbentuknya keterbukaan informasi, perlakuan adil dalam melaksanakan kewajiban serta menerima hak terhadap semua aparatur pemerintah daerah, terdapatnya pertanggungjawaban pimpinan serta partisipasi dari seluruh aparatur pemerintah daerah dalam meningkatkan kinerja yang lebih baik (Dhiyavani, 2017). Good government governance adalah suatu penyelenggaraan manajemen pembangunan yang solid dan bertanggungjawab yang sejalan dengan prinsip 
demokrasi dan pasar yang efisien, penghindaran salah alokasi dana investasi dan pencegahan korupsi baik secara politik maupun administratif, menjalalankan disiplin angaran serta penciptaan legal political framework bagi tumbuhnya aktivitas usaha (World Bank sebagaimana dikutip dari Mardiasmo, 2009:18). Selama ini birokrasi di daerah dianggap tidak kompeten, sehingga dalam kondisi demikian pemerintah daerah selalu diragukan kapasitasnya dalam menjalankan desentralisasi. Di sisi lain, pemerintah daerah juga harus mereformasi diri dari pemerintahan yang korupsi menjadi pemerintahan yang bersih dan transparan (Ramadhan dan Rahayu, 2015). Dengan demikian good government governance dapat menjadi mediasi hubungan antara kinerja aparatur pemerintah daerah dan kualitas laporan keuangan sehingga diajukan hipotesis sebagai berikut:

$\mathrm{H}_{7}$ : Kinerja aparatur pemerintah daerah berpengaruh terhadap kualitas laporan keuangan melalui good government governance sebagai variabel intervening.

\section{Metode Penelitian}

Jenis penelitian yang digunakan yaitu eksplanatori dengan pendekatan kuantitatif. Penelitian ini dilakukan pada seluruh OPD Pemerintah Kabupaten Lombok Tengah, yaitu sebanyak 32 OPD. Populasi penelitian merupakan seluruh pegawai pada 32 OPD Pemerintah Kabupaten Lombok Tengah yang berjumlah 160 orang yang terdiri dari: 32 kepala subbagian keuangan dan perencanaan, 32 bendahara penerimaan, 32 bendahara pengeluaran, dan 64 staf subbagian keuangan dan akuntansi. Pengambilan sampel penelitian menggunakan teknik non probability sampling yakni purposive sampling. Adapun kriteria tertentu dari sampel tersebut yaitu: pegawai ASN, pegawai yang melaksanakan fungsi penganggaran dan akuntansi/keuangan, pegawai yang terlibat langsung dalam implementasi SIMDA Keuangan pada OPD Pemerintah Kabupaten Lombok Tengah.

Variabel-variabel yang digunakan dalam penelitian ini terdiri atas tiga macam yaitu: variabel independen $(\mathrm{X})$, variabel dependen $(\mathrm{Y})$, dan variabel intervening $(\mathrm{Z})$. Variabel independen yang diteliti di antaranya: implementasi SIMDA $\left(\mathrm{X}_{1}\right)$ yang diukur dengan perangkat dan pengelolaan data keuangan. Sedangkan kinerja aparatur pemerintah daerah $\left(\mathrm{X}_{2}\right)$ diukur dengan proses dan hasil. Variabel dependen yang diteliti adalah kualitas laporan keuangan (Y) yang diukur dengan kriteria relevan, andal, dapat dibandingkan, dan dapat dipahami. Variabel intervening yang diteliti adalah good government governance ( $\mathrm{Z})$ yang diukur dengan akuntabilitas, transparansi, penerapan hukum, responsivitas, dan keadilan atau kesetaraan.

Prosedur pengambilan dan pengumpulan data yang digunakan, yaitu: kuesioner, wawancara, dan studi kepustakaan. Sumber data yang digunakan dalam penelitian ini adalah data primer. Data primer dalam penelitian ini adalah data yang diperoleh melalui kuesioner yang disebarkan kepada responden, yaitu kepala subbagian keuangan dan perencanaan, bendahara pengeluaran, dan staf subbagian keuangan dan akuntansi. Prosedur analisis data dalam penelitian ini terdiri dari analisis statistik deskriptif, uji kualitas data, uji asumsi klasik, dan analisis jalur (path analysis) untuk pengujian hipotesis dengan model persamaan sebagai berikut: 


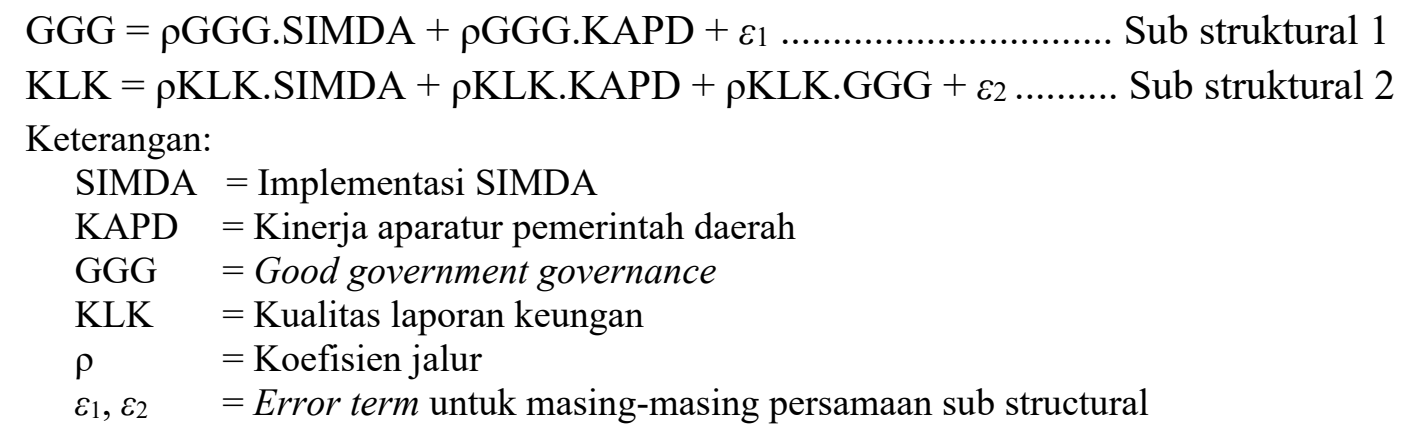

Penelitian yang melibatkan variabel mediator atau intervening lazimnya menekankan pada pentingnya penilaian peranan variabel mediator, sehingga pada penelitian ini dilakukan uji Intervening Regression Analysis (IRA) sebagaimana dirujuk dari Hair et. al. (2009:223226) dan uji Sobel (Sobel Test) (1982). Uji Sobel bertujuan untuk menguji kekuatan pengaruh tidak langsung $\mathrm{X}$ ke $\mathrm{Y}$ melalui $\mathrm{Z}$ atau dengan kata lain pengaruh mediasi atas hubungan antara variabel independen dengan variabel dependen. Pengaruh tidak langsung $X \rightarrow Y$ melalui $Z$ dihitung dengan cara mengalikan jalur $X \rightarrow Z$ (a) dengan jalur $Z \rightarrow Y$ (b) atau $a b$. Jadi koefisien $a b=\left(c-c^{\prime}\right)$ dimana $c$ adalah pengaruh $X \rightarrow Y$ tanpa mengontrol $Z$, sedangkan $\mathrm{c}^{\prime}$ adalah koefisien pengaruh $\mathrm{X} \rightarrow \mathrm{Y}$ setelah mengontrol M. Standard error koefisien a dan $\mathrm{b}$ ditulis dengan $\mathrm{Sa}$ dan $\mathrm{Sb}$ dan besarnya standard error pengaruh tidak langsung (indirect effect) adalah Sab yang dihitung dengan rumus sebagai berikut :

$$
\mathrm{s}_{\mathrm{ab}}=\sqrt{b^{2} s_{a}^{2}+a^{2} s_{b}^{2}+s_{a}^{2} s_{b}^{2}}
$$

Keterangan:

a $\quad$ koefisien regresi dari variabel independen terhadap variabel mediator

$\mathrm{S}_{\mathrm{a}} \quad=$ standard error dari a

$\mathrm{b} \quad=$ koefisien regresi dari variabel mediator terhadap variabel dependen

$\mathrm{S}_{\mathrm{b}}=$ standard error dari $\mathrm{b}$

Untuk menguji signifikansi pengaruh tidak langsung, maka perlu dihitung nilai t dari koefisien dengan rumus $\mathrm{t}=\frac{a b}{s_{a b}}$ sebagai berikut:

Nilai thitung dibandingkan dengan nilai tabel dan jika nilai t-hitung lebih besar dengan tingkat signifikansi 0,05 maka dapat disimpulkan bahwa terjadi pengaruh mediasi (Ghozali, 2016).

\section{Hasil dan Pembahasan}

4.1. Evaluasi Hasil Pengujian Statistik

Data yang dikumpulkan dari responden merupakan data primer yang diperoleh dari penyebaran kuesioner yang dilakukan secara bertahap dalam kurun waktu \pm 3 bulan kepada masing-masing OPD Pemerintah Kabupaten Lombok Tengah. Dari 96 kuisioner yang disebarkan hanya 82 atau sebesar $85,42 \%$ yang dikembalikan dan diisi dengan lengkap. Terdapat 14 kuesioner yang tidak dikembalikan atau sebesar $14,58 \%$ dari total seluruh kuesioner yang disebar sehingga jumlah kuesioner yang dapat diolah sebanyak 82 kuesioner atau memiliki response rate sebesar $85,42 \%$ dari total keseluruhan kuesioner yang disebar. Rincian penerimaan dan pengembalian kuisioner dapat dilihat pada tabel 2 berikut ini : 
Tabel 2. Rincian Penerimaan dan Pengembalian Kuesioner

\begin{tabular}{lc}
\hline \multicolumn{1}{c}{ Keterangan } & Jumlah \\
\hline Total Penyebaran Kuesioner & 96 \\
Kuesioner yang kembali & 82 \\
Kuesioner yang tidak kembali & 14 \\
Total kuesioner yang digunakan & 82 \\
Tingkat pengembalian (response rate) & $85,42 \%$ \\
\hline
\end{tabular}

Statistik deskriptif menunjukkan bahwa untuk variabel implementasi SIMDA memiliki mean sebesar 36,7805 dengan standar deviasi sebesar 4,1841, serta memiliki nilai skewness dan kurtosis masing-masing sebesar -0,361 dan -0,946 yang artinya bahwa variabel implementasi SIMDA terdistribusi secara normal karena nilai skewness dan kurtosis mendekati nol. Pada variabel kinerja aparatur pemerintah daerah memiliki mean sebesar 25,5976 dengan standar deviasi sebesar 2,6004, serta memiliki nilai skewness dan kurtosis masing-masing sebesar $-0,174$ dan 0,171 yang artinya bahwa variabel kinerja aparatur pemerintah daerah terdistribusi secara normal karena memiliki nilai skewness dan kurtosis mendekati nol. Sementara, untuk variabel kualitas laporan keuangan memiliki mean sebesar 47,3902 dengan standar deviasi sebesar 4,4019, serta memiliki nilai skewness dan kurtosis masing-masing sebesar -0,443 dan 0,449 yang artinya bahwa variabel kualitas laporan keuangan terdistribusi secara normal karena memiliki nilai skewness dan kurtosis mendekati nol. Dan untuk variabel good government governance memiliki mean sebesar 34,8659 dengan standar deviasi sebesar 3,1141, serta memiliki nilai skewness dan kurtosis masing-masing sebesar -0,292 dan 0,588 yang artinya bahwa variabel kualitas laporan keuangan terdistribusi secara normal karena memiliki nilai skewness dan kurtosis mendekati nol. Hasil pengujian statistik despkriptif disajikan pada tabel 3 berikut ini :

Tabel 3. Hasil Analisis Statistik Deskriptif

\begin{tabular}{lccccccc}
\hline & $\mathrm{N}$ & Mean & \multicolumn{2}{c}{ Std. Dev. } & \multicolumn{2}{c}{ Skewness } & \multicolumn{2}{c}{ Kurtosis } \\
\cline { 2 - 7 } & Statistic & Statistic & Statistic & Statistic & Std. Error & Statistic & Std. Error \\
\hline Implementasi SIMDA & 82 & 36.7805 & 4.1841 & -.361 & .266 & -.946 & .526 \\
Kinerja APD & 82 & 25.5976 & 2.6004 & -.174 & .266 & .171 & .526 \\
Kualitas Laporan Keuangan & 82 & 47.3902 & 4.4019 & -.443 & .266 & .449 & .526 \\
GGG & 82 & 34.8659 & 3.1141 & -.292 & .266 & .588 & .526 \\
Valid N (listwise) & 82 & & & & & & \\
\hline
\end{tabular}

Hasil pengujian validitas dan reliabilitas instrumen penelitian disajikan pada tabel 4 . Berdasarkan tabel 4 tersebut dapat diketahui bahwa jumlah responden pada penelitian ini sebanyak 82 responden, maka nilai diperoleh rtabel sebesar 0,215, di mana hasil dari rabel tersebut didapatkan dari Tabel r. Angka rtabel tersebut kemudian dibandingkan dengan nilai rhitung yang telah diketahui dengan ketentuan yaitu: jika rhitung $>r_{\text {tabel }}$ maka variabel tersebut valid, dan jika rhitung $<\mathrm{r}_{\text {tabel }}$ maka variabel tersebut tidak valid, sehingga dapat disimpulkan bahwa semua item pernyataan pada kuesioner penelitian adalah valid. Hal tersebut dikarenakan $r$ hitung pada tiap item pernyataan lebih besar dari $r$ tabel atau di atas 0,215. Hasil uji reliabilitas menunjukkan bahwa setiap variabel menunjukkan nilai Cronbach's Alpha $>0,60$. Pada variabel implementasi SIMDA memiliki nilai CA 0,835 $>0,60$. Variabel kinerja aparatur pemerintah daerah memiliki nilai CA $0,707>0,60$. Variabel 
Kualitas Laporan Keuangan memiliki nilai CA 0,796 > 0,60. Serta variabel good government governance memiliki nilai CA 0,672 >0,60. Dengan demikian dapat disimpulkan bahwa kuesioner yang digunakan dalam penelitian ini bersifat reliabel atau konsisten.

Tabel 4. Hasil Uji Validitas dan Reliabilitas Instrumen Penelitian

\begin{tabular}{|c|c|c|c|c|c|c|c|}
\hline No. & Variabel & & $r_{\text {hitung }}$ & $\mathrm{r}_{\text {tabel }}$ & Hasil & $\begin{array}{c}\text { Cronbach's } \\
\text { Alpha }\end{array}$ & Hasil \\
\hline \multirow[t]{10}{*}{1.} & Implementasi SIMDA & $\mathrm{X}_{1.1}$ & 0,706 & 0,215 & Valid & \multirow{10}{*}{0,835} & \multirow{10}{*}{ Reliabel } \\
\hline & & $\mathrm{X}_{1.2}$ & 0,685 & 0,215 & Valid & & \\
\hline & & $\mathrm{X}_{1.3}$ & 0,628 & 0,215 & Valid & & \\
\hline & & $\mathrm{X}_{1.4}$ & 0,657 & 0,215 & Valid & & \\
\hline & & $\mathrm{X}_{1.5}$ & 0,409 & 0,215 & Valid & & \\
\hline & & $\mathrm{X}_{1.6}$ & 0,725 & 0,215 & Valid & & \\
\hline & & $\mathrm{X}_{1.7}$ & 0,580 & 0,215 & Valid & & \\
\hline & & $\mathrm{X}_{1.8}$ & 0,704 & 0,215 & Valid & & \\
\hline & & $\mathrm{X}_{1.9}$ & 0,458 & 0,215 & Valid & & \\
\hline & & $\mathrm{X}_{1.10}$ & 0,783 & 0,215 & Valid & & \\
\hline \multirow[t]{7}{*}{2.} & Kinerja APD & $\mathrm{X}_{2.1}$ & 0,728 & 0,215 & Valid & \multirow{7}{*}{0,707} & \multirow{7}{*}{ Reliabel } \\
\hline & & $\mathrm{X}_{2.2}$ & 0,715 & 0,215 & Valid & & \\
\hline & & $\mathrm{X}_{2.3}$ & 0,722 & 0,215 & Valid & & \\
\hline & & $\mathrm{X}_{2.4}$ & 0,551 & 0,215 & Valid & & \\
\hline & & $\mathrm{X}_{2.5}$ & 0,484 & 0,215 & Valid & & \\
\hline & & $\mathrm{X}_{2.6}$ & 0,515 & 0,215 & Valid & & \\
\hline & & $\mathrm{X}_{2.7}$ & 0,604 & 0,215 & Valid & & \\
\hline \multirow[t]{13}{*}{3.} & Kualitas Laporan & $\mathrm{Y}_{1}$ & 0,423 & 0,215 & Valid & \multirow{13}{*}{0,796} & \multirow{13}{*}{ Reliabel } \\
\hline & Keuangan & $Y_{2}$ & 0,411 & 0,215 & Valid & & \\
\hline & & $\mathrm{Y}_{3}$ & 0,415 & 0,215 & Valid & & \\
\hline & & $Y_{4}$ & 0,460 & 0,215 & Valid & & \\
\hline & & $\mathrm{Y}_{5}$ & 0,418 & 0,215 & Valid & & \\
\hline & & $Y_{6}$ & 0,470 & 0,215 & Valid & & \\
\hline & & $\mathrm{Y}_{7}$ & 0,625 & 0,215 & Valid & & \\
\hline & & $\mathrm{Y}_{8}$ & 0,414 & 0,215 & Valid & & \\
\hline & & $\mathrm{Y}_{9}$ & 0,435 & 0,215 & Valid & & \\
\hline & & $\mathrm{Y}_{10}$ & 0,671 & 0,215 & Valid & & \\
\hline & & $\mathrm{Y}_{11}$ & 0,779 & 0,215 & Valid & & \\
\hline & & $\mathrm{Y}_{12}$ & 0,713 & 0,215 & Valid & & \\
\hline & & $\mathrm{Y}_{13}$ & 0,685 & 0,215 & Valid & & \\
\hline \multirow[t]{10}{*}{4.} & GGG & $\mathrm{Z}_{1}$ & 0,375 & 0,215 & Valid & \multirow{10}{*}{0,672} & \multirow{10}{*}{ Reliabel } \\
\hline & & $\mathrm{Z}_{2}$ & 0,420 & 0,215 & Valid & & \\
\hline & & $\mathrm{Z}_{3}$ & 0,698 & 0,215 & Valid & & \\
\hline & & $\mathrm{Z}_{4}$ & 0,346 & 0,215 & Valid & & \\
\hline & & $\mathrm{Z}_{5}$ & 0,433 & 0,215 & Valid & & \\
\hline & & $\mathrm{Z}_{6}$ & 0,564 & 0,215 & Valid & & \\
\hline & & $\mathrm{Z}_{7}$ & 0,598 & 0,215 & Valid & & \\
\hline & & $\mathrm{Z}_{8}$ & 0,586 & 0,215 & Valid & & \\
\hline & & $\mathrm{Z}_{9}$ & 0,301 & 0,215 & Valid & & \\
\hline & & $\mathrm{Z}_{10}$ & 0,698 & 0,215 & Valid & & \\
\hline
\end{tabular}

Hasil uji normalitas yang dilakukan melalui uji Kolmogorov-Smirnov (K-S) menunjukkan bahwa pada persamaan sub struktural pertama besarnya nilai K-S yang diperoleh sebesar 1,350 dan signifikan pada 0,052. Demikian juga halnya untuk persamaan sub struktural kedua, nilai K-S yang diperoleh sebesar 0,914 dan signifikan pada 0,373. Nilai signifikan pada persamaan sub struktural pertama dan kedua tersebut lebih besar dari $0,05(0,052>0,05$ dan 0,373>0,05), maka dapat diambil disimpulkan bahwa melalui uji normalitas dengan menggunakan uji K-S terbukti data residual terdistribusi normal. Hasil 
pengujian multikolinieritas menunjukkan bahwa untuk persamaan sub struktural pertama dan sub struktural kedua (untuk variabel implementasi SIMDA dan kinerja aparatur daerah) didapatkan nilai tolerance untuk setiap variabel dengan nilai tolerance tersebut lebih besar dari 0,10 atau nilai tolerance $\geq 0,10$. Sedangkan nilai VIF untuk untuk persamaan sub struktural pertama dan sub struktural kedua untuk masing-masing variabel memiliki nilai VIF tersebut kurang dari 10 atau nilai VIF $\leq 10$. Dengan demikian berdasarkan nilai tolerance dan VIF tersebut dapat disimpulkan bahwa untuk persamaan sub struktural pertama dan sub struktural kedua tidak terjadi multikolinieritas. Hasil pengujian normalitas dan multikolinearitas yang disajikan pada tabel 5 berikut ini :

Tabel 5. Hasil Uji Normalitas dan Uji Multikolinieritas

\begin{tabular}{llllll}
\hline Model & Variabel & $\begin{array}{l}\text { Kolmogorov- } \\
\text { Smirnov(Z) }\end{array}$ & $\begin{array}{l}\text { Asymp. Sig. } \\
\text { (2-tailed) }\end{array}$ & Tolerance & VIF \\
\hline Persamaan Sub & Implementasi SIMDA & \multirow{2}{*}{1,350} & 0,052 & 0,647 & 1,546 \\
Struktural 1 & Kinerja APD & & & 0,647 & 1,546 \\
\hline Persamaan Sub & Implementasi SIMDA & & 0,373 & 0,635 & 1,575 \\
Struktural 2 & Kinerja APD & 0,914 & & 0,488 & 2,049 \\
& GGG & & & 0,720 & 1,389 \\
\hline
\end{tabular}

Hasil pengujian Heteroskedastisitas dapat dilihat pada gambar 1. Dengan menggunakan grafik sctterplot menunjukkan bahwa titik-titik menyebar secara acak serta tersebar baik di atas maupun di bawah angka 0 pada sumbu $\mathrm{Y}$ atau dapat dikatakan bahwa tidak terjadi heteroskedastisitas pada model regresi sehingga model regresi ini layak untuk digunakan.

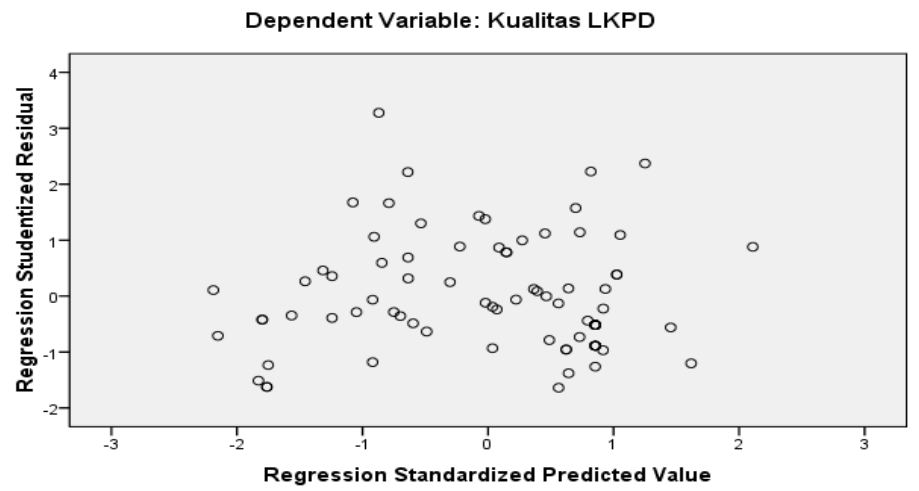

Gambar 1. Grafik Scatterplot Uji Heteroskedastisitas

Hasil pengujian terhadap koefisien determinasi $\left(\mathrm{R}^{2}\right)$ dan $\mathrm{F}$ dapat dilihat pada tabel 6 . Hasil pengujian $\left(\mathrm{R}^{2}\right)$ menunjukkan bahwa persamaan sub struktural pertama diperoleh nilai Adjusted $R^{2}$ sebesar 0,262. Hal tersebut menunjukkan bahwa pada persamaan sub struktural pertama dalam penelitian ini sebesar $26,2 \%$ variasi good government governance dapat dijelaskan oleh implementasi SIMDA dan kinerja aparatur pemerintah daerah, sedangkan sisanya dijelaskan oleh faktor lain di luar model. Sementara perhitungan yang dilakukan pada persamaan sub struktural kedua menghasilkan nilai Adjusted $R^{2}$ sebesar 0,617, Hal tersebut berarti bahwa pada persamaan ini sebesar $61,7 \%$ variasi kualitas laporan keuangan dapat dijelaskan oleh implemtasi SIMDA, kinerja aparatur pemerintah daerah, dan good government governance, sedangkan sisanya dijelaskan oleh faktor lain di luar model. 
Hasil pengujian $\mathrm{F}$ menunjukkan bahwa terdapat pengaruh simultan implementasi SIMDA dan kinerja aparatur pemerintah daerah terhadap good government governance

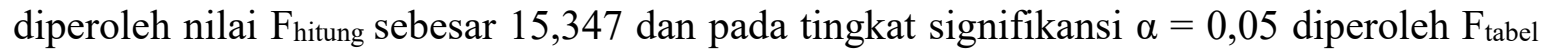
sebesar 3,11. Dengan membandingkan nilai $\mathrm{F}$ hasil perhitungan dengan tabel $\mathrm{F}$ dapat

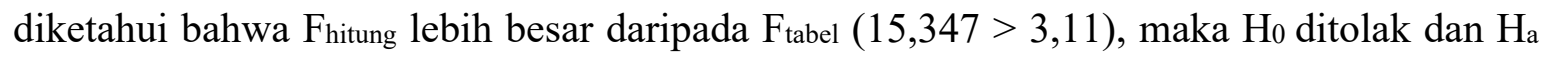
diterima, artinya implementasi SIMDA dan kinerja aparatur pemerintah daerah secara simultan berpengaruh terhadap good government governance. Nilai signifikansi yang dihasilkan juga lebih kecil dari $0,05(0,000<0,005)$, maka model regresi dapat digunakan untuk memprediksi good government governance. Tabel 6 juga menunjukkan hasil pengujian pengaruh simultan implementasi SIMDA, kinerja aparatur pemerintah daerah dan good government governance terhadap kualitas laporan keuangan yang ditunjukkan oleh nilai $F_{\text {hitung }}$ sebesar 44,519 dan pada tingkat signifikansi $\alpha=0,05$ diperoleh $F_{\text {tabel }}$ sebesar 2,72. Dari hasil tersebut tampak bahwa Fhitung lebih besar daripada $F_{\text {tabel }}(44,519>$ 2,72), maka $\mathrm{H}_{0}$ ditolak dan $\mathrm{H}_{\mathrm{a}}$ diterima, artinya implementasi SIMDA, kinerja aparatur pemerintah daerah, dan good government governance secara simultan berpengaruh terhadap kualitas laporan keuangan. Nilai signifikansi. yang dihasilkan lebih kecil dari 0,05 sehingga model regresi dapat digunakan untuk memprediksi kualitas laporan keuangan.

Tabel 6. Hasil Uji Koefisien Determinan $\left(\mathrm{R}^{2}\right)$ dan Uji F

\begin{tabular}{ccccc}
\hline Model & Adjusted $R^{2}$ & $\mathrm{~F}_{\text {hitung }}$ & $\mathrm{F}_{\text {tabel }}$ & Sig. \\
\hline Persamaan Sub Struktural 1 & 0,262 & 15,347 & 3,11 & 0,000 \\
Persamaan Sub Struktural 2 & 0,617 & 44,519 & 2,72 & 0,000 \\
\hline
\end{tabular}

Hasil pengujian hipotesis (uji t) pada tabel 7 dapat diketahui bahwa hipotesis pertama $\left(\mathrm{H}_{1}\right)$ menemukan bahwa thitung implementasi SIMDA terhadap good government governance sebesar -1,211 lebih kecil dari tabel 1,665 dengan tingkat signifikansi di atas $\alpha$ $=0,05$ atau tidak signifikan (nilai Sig. 0,229>0,05) dan berarah negatif. Dengan demikian hipotesis kedua $\left(\mathrm{H}_{2}\right)$ ditolak. Pada persamaan sub struktural kedua, hipotesis kedua $\left(\mathrm{H}_{2}\right)$ menemukan bahwa thitung implementasi SIMDA terhadap kualitas laporan keuangan sebesar 8,924 lebih besar dari tabel 1,664 dengan tingkat signifikansi di bawah $\alpha=0,05$ atau signifikan (nilai Sig. $0,000<0,05$ ) dan berarah positif. Dengan demikian hipotesis kedua $\left(\mathrm{H}_{2}\right)$ diterima, artinya implementasi SIMDA berpengaruh positif terhadap kualitas laporan keuangan. Pada persamaan sub struktural pertama, hipotesis ketiga $\left(\mathrm{H}_{3}\right)$ menemukan bahwa thitung kinerja aparatur pemerintah daerah terhadap good government governance sebesar 5,068 lebih besar dari tabel 1,665 dengan tingkat signifikansi di bawah $\alpha=0,05$ atau signifikan (nilai Sig. $0,000<0,05$ ) dan berarah positif. Dengan demikian hipotesis alternatif ketiga $\left(\mathrm{H}_{3}\right)$ diterima, artinya kinerja aparatur pemerintah daerah berepngaruh terhadap good government governance. Pada persamaan sub struktural kedua, hasil pengujian hipotesis keempat $\left(\mathrm{H}_{4}\right)$ menemukan bahwa thitung kinerja aparatur pemerintah daerah terhadap kualitas laporan keuangan sebesar -0,354 lebih kecil dari tabel 1,664 dengan tingkat signifikansi di atas $\alpha=0,05$ atau tidak signifikan (nilai Sig. 0,724> $0,05)$ dan berarah negatif. Dengan demikian hipotesis keempat $\left(\mathrm{H}_{4}\right)$ ditolak, artinya kinerja aparatur pemerintah daerah tidak berpengaruh terhadap kualitas laporan keuangan. Pada persamaan sub struktural kedua, hipotesis kelima $\left(\mathrm{H}_{5}\right)$ menemukan bahwa thitung good 
government governance terhadap kualitas laporan keuangan sebesar 1,907 lebih besar dari tabel 1,664 dengan tingkat signifikansi di atas $\alpha=0,05$ atau tidak signifikan (nilai Sig. $0,060>0,05)$ dan berarah positif. Dengan demikian hipotesis alternatif kelima $\left(\mathrm{H}_{5}\right)$ diterima, artinya good government governance berpengaruh positif terhadap kualitas laporan keuangan.

Tabel 7. Hasil Uji Signifikansi Parameter Individual (Uji t)

\begin{tabular}{lccccccc}
\hline \multicolumn{1}{c}{ Model } & Hipotesis & $\begin{array}{c}\text { Hubungan } \\
\text { Variabel }\end{array}$ & $\begin{array}{c}\text { Arah Hubungan } \\
(+/-)\end{array}$ & $\mathrm{t}_{\text {hitung }}$ & $\mathrm{t}_{\text {tabel }}$ & $\mathrm{Sig}$ & Kesimpulan \\
\hline $\begin{array}{l}\text { Persamaan } \\
\text { Sub }\end{array}$ & $\mathrm{H}_{1}$ & $\mathrm{X}_{1} \rightarrow \mathrm{Z}$ & $-0,144$ & $-1,211$ & 1,665 & 0,229 & $\mathrm{H}_{\mathrm{a}}$ ditolak \\
Struktural 1 & $\mathrm{H}_{3}$ & $\mathrm{X}_{2} \rightarrow \mathrm{Z}$ & 0,602 & 5,068 & 1,665 & 0,000 & $\mathrm{H}_{\mathrm{a}}$ diterima \\
Persamaan & $\mathrm{H}_{2}$ & $\mathrm{X}_{1} \rightarrow \mathrm{Y}$ & 0,770 & 8,924 & 1,664 & 0,000 & $\mathrm{H}_{\mathrm{a}}$ diterima \\
Sub & $\mathrm{H}_{4}$ & $\mathrm{X}_{2} \rightarrow \mathrm{Y}$ & $-0,035$ & $-0,354$ & 1,664 & 0,724 & $\mathrm{H}_{\mathrm{a}}$ ditolak \\
Struktural 2 & $\mathrm{H}_{5}$ & $\mathrm{Z} \rightarrow \mathrm{Y}$ & 0,154 & 1,907 & 1,664 & 0,060 & $\mathrm{H}_{\mathrm{a}}$ diterima \\
\hline
\end{tabular}

Hasil pengujian Intervening Regression Analysis (IRA) dan pendeteksian efek mediator melalui evaluasi VAF dapat dilihat pada Tabel 8. Hasil tersebut menunjukkan bahwa nilai pengaruh langsung untuk variabel $X_{1} \rightarrow Z$ sebesar $-0,144$, variabel $X_{1} \rightarrow Y$ sebesar 0,770, variabel $X_{2} \rightarrow Z$ sebesar 0,602 , variabel $X_{2} \rightarrow Y$ sebesar $-0,035$, variabel $Z$ $\rightarrow \mathrm{Y}$ sebesar 0,154. Nilai pengaruh tidak langsung untuk variabel $\mathrm{X}_{1} \rightarrow \mathrm{Z} \rightarrow \mathrm{Y}$ sebesar 0,275 , dan variabel $X_{2} \rightarrow Z \rightarrow Y$ sebesar 1,148 . Nilai pengaruh total untuk variabel $X_{1} \rightarrow$ $\mathrm{Z} \rightarrow \mathrm{Y}$ sebesar 0,495, dan variabel $\mathrm{X}_{2} \rightarrow \mathrm{Z} \rightarrow \mathrm{Y}$ sebesar 1,113. Sedangkan hasil pendeteksian efek mediator melalui evaluasi VAF untuk variabel $\mathrm{X}_{1} \rightarrow \mathrm{Z} \rightarrow \mathrm{Y}$ sebesar 0,556 , artinya bahwa tidak terdapat mediator hubungan antara pengaruh implementasi SIMDA terhadap kualitas laporan keuangan (VAF $<0,20$ artinya peranan mediator nihil). Serta variabel $\mathrm{X}_{2} \rightarrow \mathrm{Z} \rightarrow \mathrm{Y}$ sebesar 1,031, artinya bahwa terdapat mediator penuh hubungan antara pengaruh kinerja aparatur pemerintah daerah terhadap kualitas laporan keuangan (VAF $>0,80$ artinya peranan mediator kuat atau penuh).

Tabel 8. Hasil Uji Intervening Regression Analysis (IRA) dan Evaluasi VAF

\begin{tabular}{lccccccc}
\hline \multicolumn{1}{c}{ Variabel } & $\begin{array}{c}\text { Pengaruh } \\
\text { Langsung }\end{array}$ & \multicolumn{2}{c}{ Pengaruh Tidak Langsung } & $\begin{array}{c}\text { Pengaruh } \\
\text { Total }\end{array}$ & VAF & Keterangan \\
\hline Implementasi SIMDA & 0,770 & $-0,144$ & 1,907 & $-0,275$ & 0,495 & $-0,556$ & Mediator Nihil \\
Kinerja APD & $-0,035$ & 0,602 & 1,907 & 1,148 & 1,113 & 1,031 & Mediator Penuh \\
$G G G$ & 0,154 & & & & & & \\
\hline
\end{tabular}

Hasil pengujian Sobel Model I dan Model II disajikan pada Tabel 9. Uji Sobel Model I dilakukan untuk variabel $\mathrm{X}_{1} \rightarrow \mathrm{Z} \rightarrow \mathrm{Y}$ menunjukkan hasil perhitungan $\mathrm{S}_{\mathrm{ab}}$ sebesar 0,063 dengan nilai tabel $>$ thitung atau 1,665 $>-0,365$, artinya pengaruh implementasi SIMDA terhadap kualitas laporan keuangan melalui good government governance sebagai variabel intervening tidak signifikan atau dapat dikatakan bahwa good government governance bukan merupakan mediator hubungan antara implementasi SIMDA dan kualitas laporan keuangan. Hasil pendeteksian variabel mediator atau intervening melalui perhitungan dan evaluasi VAF serta uji Sobel Model I tersebut dapat menjawab hipotesis keenam $\left(\mathrm{H}_{6}\right)$. Uji Sobel Model II dilakukan untuk variabel $\mathrm{X}_{2} \rightarrow \mathrm{Z} \rightarrow \mathrm{Y}$ menunjukkan hasil perhitungan $\mathrm{S}_{\mathrm{ab}}$ sebesar 0,0899 dengan nilai tabel $>$ thitung atau 1,665 $<1,746$, variasi artinya pengaruh kinerja aparatur pemerintah daerah terhadap kualitas laporan keuangan melalui good 
government governance sebagai variabel intervening signifikan atau dapat dikatakan bahwa good government governance merupakan mediator hubungan antara kinerja aparatur pemerintah daerah dan kualitas laporan keuangan. Hasil pendeteksian variabel mediator atau intervening melalui perhitungan dan evaluasi VAF serta uji Sobel Model II tersebut dapat menjawab hipotesis ketujuh $\left(\mathrm{H}_{7}\right)$ pada penelitian ini.

Tabel 9. Hasil Uji Sobel

\begin{tabular}{|c|c|c|c|c|c|c|c|c|}
\hline $\begin{array}{l}\text { Variabel } \\
\text { Independen }\end{array}$ & $\mathrm{a}$ & $\mathrm{S}_{\mathrm{a}}$ & $t_{\text {hitung }}$ & $\mathrm{t}_{\text {tabel }}$ & $\begin{array}{l}\text { Variabel } \\
\text { Mediator }\end{array}$ & B & $\mathrm{S}_{\mathrm{b}}$ & $\mathrm{S}_{\mathrm{ab}}$ \\
\hline $\begin{array}{l}\text { Impelementasi } \\
\text { SIMDA }\end{array}$ & $-0,107$ & 0,088 & $-0,365$ & 1,665 & $\begin{array}{c}\text { Good } \\
\text { Government }\end{array}$ & 0,218 & 0,115 & 0,063 \\
\hline $\begin{array}{l}\text { Kineja Aparatur } \\
\text { Pemda }\end{array}$ & 0,721 & 0,142 & 1,746 & 1,665 & Governance & & & 0,0899 \\
\hline
\end{tabular}

\subsection{Pembahasan}

Hasil pengujian hipotesis pertama $\left(\mathrm{H}_{1}\right)$ menunjukkan bahwa implementasi SIMDA berpengaruh negatif tidak signifikan terhadap good government governance. Hasil dari penelitian ini sejalan dengan studi Sari (2013) yang menemukan bahwa implementasi SIMDA tidak berpengaruh terhadap good government governance. Hal tersebut menunjukkan bahwa implementasi SIMDA yang baik tidak selalu diikuti oleh terwujudnya good government governance pada pemerintah daerah dengan baik, dan sebaliknya. Namun demikian hasil penelitian ini tidak sejalan dengan hasil studi yang dilakukan oleh Dhiyavani (2017) yang menemukan hasil bahwa implementasi SIMDA berpengaruh terhadap penerapan good government governance. Berdasarkan hasil penelitian menunjukkan bahwa perangkat yang digunakan dalam mendukung implementasi SIMDA sudah baik dan output data keuangan yang dihasilkan oleh aplikasi SIMDA Keuangan sudah bagus. Akan tetapi, terdapat beberapa alasan argumentatif yang menjadi indikasi implementasi SIMDA tidak berperan dalam mewujudkan good government governance pada penelitian ini, di antaranya : masih rendahnya tingkat pemahaman para pengelola keuangan, kurangnya sarana dan prasarana pendukung dalam pelaksanaan implementasi SIMDA, serta faktor peralatan (tools). Pelatihan SIMDA telah dilakukan beberapa kali oleh pemerintah daerah kepada para pengelola keuangan agar aplikasi SIMDA dapat diimplementasikan secara optimal guna mewujudkan good government governance, namun penelitian ini membuktikan bahwa implementasi SIMDA pada OPD belum mampu memenuhi tuntutan masyarakat selaku pihak principals dalam mewujudkan good government governance.

Pengujian hipotesis kedua menunjukkan hasil bahwa implementasi SIMDA berpengaruh signifikan positif terhadap kualitas laporan keuangan. Hasil penelitian ini sejalan dengan studi yang dilakukan oleh Runtuwene, dkk. (2017) yang menguji pengaruh penerapan SIMDA, SAP, motivasi pegawai dan kinerja SDM terhadap kualitas laporan keuangan pada Pemerintah Kabupaten Minahasa. Hasil penelitian tersebut menemukan bahwa implementasi SIMDA berpengaruh terhadap kualitas laporan keuangan. Penelitian ini juga mendukung studi yang dilakukan oleh Kamal dan Noermansyah (2015), serta Pulungan (2014). Hasil dari penelitian-penelitian tersebut menunjukkan bahwa semakin tinggi implementasi SIMDA maka laporang keuangan yang dihasilkan pemerintah daerah 
akan semakin berkualitas. Begitu pun sebaliknya, semakin rendah implementasi SIMDA maka laporang keuangan yang dihasilkan pemerintah daerah akan semakin tidak berkualitas. Walaupun terdapat beberapa penelitian yang sejalan dengan hasil penelitian ini, akan tetapi terdapat pula penelitian yang hasilnya tidak sejalan dengan penelitian ini, yaitu studi yang dilakukan oleh Ole (2014) dan Sari (2013) menyatakan bahwa implementasi SIMDA tidak berpengaruh terhadap kualitas laporan keuangan. Temuan ini mengindikasikan bahwa segala kegiatan atau aktivitas aparatur pemerintah daerah dalam mendukung proses peningkatan kinerjanya sudah baik, serta output yang dihasilkan aparatur pemerintah daerah dalam meningkatkan kinerjanya cukup baik. Hal ini sesuai dengan implikasi dari teori Penatalayanan yang dikemukakan oleh Donaldson dan Davis (1991) dengan asumsi dasar bahwa sikap manajemen dalam hal ini pemerintah daerah cenderung mempertimbangkan risiko-risiko dalam penyusunan laporan keuangan, di mana pemerintah daerah tidaklah termotivasi oleh tujuan-tujuan individu tetapi lebih ditunjukkan kepada sasaran hasil utama mereka untuk kepentingan organisasi pemerintahan. Dengan demikian kewajiban pemerintah daerah sebagai pemegang amanah (stewards) untuk dapat memberikan pertanggungjawaban dalam menyajikan, melaporkan, serta mengungkapkan segala aktivitas dan kegiatan yang menjadi tanggungjawabnya dalam melaksanakan pengelolaan keuangan daerahnya secara terintegrasi, dimulai dari penganggaran, penatausahaan, akuntansi dan pelaporannya kepada pihak pemberi amanah (principals) yang memiliki hak dan wewenang untuk meminta pertanggungjawaban tersebut.

Hasil pengujian hipotesis ketiga menunjukkan bahwa kinerja aparatur pemerintah daerah berpengaruh signifikan terhadap good government governance. Dalam hal ini kinerja aparatur pemerintah daerah berpengaruh positif terhadap good government governance. Hasil penelitian ini sejalan dengan studi yang dilakukan oleh Dhiyavani (2017) yang menemukan bahwa kinerja aparatur pemerintah daerah berpengaruh terhadap good government governance. Hasil penelitian ini juga mendukung studi yang dilakukan oleh Yusniyar, dkk. (2016) yang menemukan bahwa kinerja aparatur pemerintah baik secara simultan maupun parsial berpengaruh terhadap good government governance. Temuan penelitian ini mengindikasikan bahwa pemerintah daerah selaku stewards harus dapat meningkatkan kinerja aparatur pemerintah daerah sebagai timbal balik dari kontribusi dan kepercayaan yang diberikan masyarakat (principals) kepadanya dalam mewujudkan good government governance dengan memertimbangkan faktor manusia pelaksana (man) sebagai asumsi dasar dari teori Penatalayanan. Faktor manusia pelaksana (man) dapat dilihat dari berhasil atau tidaknya pelaksanaan good government governance sebagian besar tergantung pada pemerintah daerah yang diukur dari kinerja aparatur pemerintah daerah itu sendiri atau dengan kata lain pemerintah daerah harus berperilaku kolektif untuk kepentingan organisasi. Stewards yang memiliki tindakan kolektif atau berkelompok, bekerjasama dengan utilitas tinggi dan selalu bersedia untuk melayani publik (dilihat dari segi budaya) termasuk memiliki rentang kekuasaan atau power rendah, serta berpedoman bahwa terdapat utilitas yang lebih besar pada tindakan kooperatif dan tindakan tersebut dianggap tindakan rasional yang dapat diterima untuk kepentingan organisasi, misalnya dengan melakukan efisiensi dan efektivitas serta peningkatan kinerja aparatur pemerintah daerah. Hal tersebut menandakan bahwa di setiap aktivitas aparatur pemerintah daerah harus cenderung pada prinsip good government governance, dengan 
semakin baik penjiwaan aparatur pemerintah daerah terhadap prinsip-prinsip good government governance, maka semakin baik pula peningkatan kinerja aparatur pemerintah daerah pada Organisasi Perangkat Daerah.

Hasil pengujian hipotesis keempat menunjukkan bahwa kinerja aparatur pemerintah daerah berpengaruh positif tidak sgnifikan terhadap kualitas laporan keuangan. Hasil penelitian ini sejalan dengan temuan studi yang dilakukan oleh Yusniyar, dkk. (2016) yang menyatakan bahwa kinerja aparatur pemerintah tidak memiliki pengaruh signifikan terhadap kualitas laporan keuangan. Akan tetapi, hasil penelitian ini tidak sejalan dengan studi yang dilakukan oleh Azzindani (2019), Runtuwene, dkk. (2017), Oktarina, dkk. (2016), serta Ramadhan dan Rahayu (2015), yang menyatakan bahwa kinerja aparatur pemerintah berpengaruh terhadap kualitas laporan keuangan. Beberapa alasan argumentatif dapat menjadi indikasi penelitian ini adalah bahwa kinerja aparatur pemerintah daerah tidak berperan dalam menghasilkan laporan keuangan yang berkualitas pada penelitian ini, di antaranya karena peraturan perundang-undangan yang tumpang tindih sehingga seringkali terjadi satu aturan belum sempat dipahami dan dilaksanakan dengan baik sudah muncul aturan baru yang membuat pemerintah daerah kebingungan, serta keterbatasan aparatur pemerintah daerah yang menguasai bidang akuntansi pada OPD yang tidak memahami akuntansi dengan sangat baik sehingga aparatur pemerintah daerah belum siap secara merata dalam mendukung penyusunan laporan keuangan pemerintah daerah yang berkualitas. Untuk mengatasi permasalahan yang dihadapi para pengelola keuangan, pemerintah daerah terus mendorong para pengelola keuangan selaku aparatur pemerintah daerah untuk meningkatkan kemampuan pemahaman akuntansi serta terus mendapatkan beberapa pelatihan dalam penyusunan dan pembuatan laporan keuangan agar dapat meningkatkan kinerjanya guna menghasilkan laporan keuangan pemerintah daerah yang berkualitas.

Hasil pengujian hipotesis kelima menunjukkan bahwa good government governance berpengaruh positif dan signifikan terhadap kualitas laporan keuangan. Hasil penelitian ini sejalan dengan studi yang dilakukan oleh Oktarina, dkk. (2016) dan Yusniyar, dkk. (2016) menunjukkan bahwa good government governance berpengaruh terhadap kualitas laporan keuangan. Hasil penelitian ini menunjukkan bahwa bentuk pertanggungjawaban akuntabilitas atas informasi yang disajikan dalam LAKIP sudah bagus, yang ditunjukkan oleh sudah baiknya output dari proses keterbukaan (transparansi) dalam menyampaikan informasi yang dikeluarkan pemerintah daerah, kesetaraan dalam penerapan hukum atau sanksi yang diberlakukan bagi pegawai yang melanggar peraturan sudah cukup baik, kemampuan pemerintah daerah dalam mengukur daya tanggap (responsivitas) terhadap kebutuhan masyarakat, serta keadilan dalam penempatan posisi kerja yang sudah baik. Temuan ini mengargumentasikan teori Penatalayanan, di mana pada pendekatan good goverment governance yang mempertimbangan fakor manusia pelaksana (man) dan faktor peralatan (tools) untuk menghasilkan informasi laporan keuangan yang berkualitas, maka sistem tata kelola pemerintahan yang baik harus memenuhi karakteristik kualitas laporan keuangan seperti relevan dan reliabel, sehingga laporan keuangan yang disajikan diyakini dapat digunakan dalam pengambilan keputusan. Implikasi dari teori Keagenan yang mengasumsikan pemerintah daerah selaku agents dituntut mampu memberikan informasi keuangan maupun informasi nonkeuangan secara lengkap dan akurat kepada masyarakat 
(principals). Namun demikian, terkadang informasi yang disampaikan tidak sesuai dengan keadaan yang sebenarnya, sehingga hal tersebut memicu terjadinya asimetri informasi. Keadaan asimetri informasi terjadi ketika adanya distribusi informasi yang tidak sama antara principals dan agents yang memungkinkan adanya konflik antar keduanya. Oleh karena itu, untuk meminimalisasi adanya penyimpangan yang dapat ditimbulkan konflik tersebut maka diperlukan tata kelola pemerintahan yang baik.

Hasil pengujian hipotesis keenam menunjukkan bahwa good government governance bukan merupakan mediator hubungan antara implementasi SIMDA dan kualitas laporan keuangan. Jika dilihat hasil perhitungan koefisien jalur hubungan langsung, implementasi SIMDA dapat berpengaruh positif terhadap kualitas laporan keuangan yang konsisten dengan temuan Runtuwene, dkk. (2017), Kamal dan Noermansyah (2015); dan Pulungan (2014). Sedangkan, jika dilihat hasil perhitungan koefisien jalur hubungan tidak langsung antara implementasi SIMDA dengan kualitas laporan keuangan melalui good government governance menunjukkan bahwa dengan adanya good government governance sebagai mediator justru menghasilkan hubungan tidak saling memengaruhi antara implementasi SIMDA dengan kualitas laporan keuangan. Temuan penelitian ini tidak sejalan dengan penelitian yang dilakukan oleh Dhiyavani (2017) dan Sari (2013) yang menunjukkan bahwa implementasi SIMDA berpengaruh terhadap good government governance.

Hasil pengujian hipotesis ketujuh menunjukkan bahwa good government governance dapat memediasi penuh pengaruh kinerja aparatur pemerintah daerah terhadap kualitas laporan keuangan. Dengan demikian good government governance merupakan mediator hubungan antara kinerja aparatur pemerintah daerah dan kualitas laporan keuangan. Hasil perhitungan koefisien jalur hubungan langsung, kinerja aparatur pemerintah daerah tidak memiliki pengaruh terhadap kualitas laporan keuangan yang hasil penelitan tersebut didukung oleh penelitian yang dilakukan Yusniyar, dkk. (2016). Namun demikian, hasil perhitungan koefisien jalur hubungan tidak langsung antara kinerja aparatur pemerintah daerah dengan kualitas laporan keuangan melalui good government governance menunjukkan bahwa good government governance dapat memediasi penuh antara kinerja aparatur pemerintah daerah dengan kualitas laporan keuangan. Dengan kata lain, adanya good government governance sebagai mediator menghasilkan hubungan saling memengaruhi antara kinerja aparatur pemerintah daerah dengan kualitas laporan keuangan. Hal tersebut sejalan dengan penelitian yang dilakukan oleh Dhiyavani (2017) dan Yusniyar, dkk. (2016) yang menunjukkan bahwa kinerja aparatur pemerintah daerah berpengaruh terhadap good government governance.

\section{Kesimpulan, Implikasi dan Keterbatasan}

Berdasarkan hasil penelitian, maka dapat disimpulkan bahwa implementasi SIMDA tidak berpengaruh terhadap good government governance, namun berpengaruh terhadap kualitas laporan keuangan. Implementasi SIMDA yang tidak berpengaruh terhadap good government governance dikarenakan masih rendahnya tingkat pemahaman para pengelola keuangan, kurangnya sarana dan prasarana pendukung dalam pelaksanaan implementasi SIMDA, serta faktor peralatan (tools). Penelitian ini menemukan bahwa kinerja aparatur pemerintah daerah berpengaruh terhadap good government governance, namun tidak berpengaruh terhadap kualitas laporan keuangan yang diindikasikan karena peraturan 
perundang-undangan yang tumpang tindih, keterbatasan pemahaman aparatur pemerintah daerah yang menguasai bidang akuntansi pada Organisasi Perangkat Daerah (OPD). Temuan lain penelitian ini mengungkapkan bahwa good government governance bukan merupakan mediator hubungan antara implementasi SIMDA dan kualitas laporan keuangan, namun merupakan mediator hubungan antara kinerja aparatur pemerintah daerah dan kualitas laporan keuangan. Hasil penelitian ini mengindikasikan bahwa kepala (OPD) dan pengelola keuangan harus mampu mengidentifikasi faktor-faktor yang dapat mendorong keberhasilan implementasi SIMDA sehingga dapat menghasilkan laporan keuangan yang berkualitas. Untuk mendukung pencapaian kinerja aparatur pemerintah daerah yang baik di setiap OPD perlu kebijakan yang mendukung dan proses pelaksanaan kegiatan sesuai dengan tugas dan fungsi aparatur pemerintah untuk menghasilkan output yang diukur baik dalam perspektif kinerja maupun perspektif pengelola keuangannya.

Penelitian ini memiliki beberapa keterbatasan yang dapat ditindaklanjuti dalam penelitian mendatang. Pengujian pada lingkup Organisasi Perangkat Daerah (OPD) yang lebih luas diperlukan sehingga hasil penelitian dapat diperbandingkan dengan memperhatikan karakteristik setiap pemerintah daerah. Pengujian terhadap determinan good government governance perlu dielaborasi lebih luas dalam penelitian mendatang seperti penerapan Standar Akuntansi Pemerintahan (SAP), pengendalian SPI dan komitmen organisasi. Penelitian ini menggunakan analisis jalur (path analysis) dengan metode dekomposisi karena memasukkan seluruh variabel yang diamati walaupun hasil analisis menunjukkan bahwa nilai $\mathrm{VAF}<0,20$ dan nilai $\mathrm{VAF}>0,80$. Oleh karena itu, penelitian selanjutnya diharapkan dapat menggunakan pengujian moderating dengan metode Moderated Regression Analysis (MRA).

\section{Daftar Pustaka}

Azzindani, Rahmatia, Endar Pituringsih dan M. Irwan. (2019). Pengaruh Implementasi SIMDA, Kinerja Aparatur Pemerintah Daerah, dan Penerapan SAP Terhadap Kualitas LKPD Lombok Tengah. E-Jurnal Akuntansi Universitas Udayana, 27 (1), 418-445.

Bastian, Indra. (2010). Akuntansi Sektor Publik di Indonesia. Yogyakarta: BPFE.

Dhiyavani, Siti Indah. (2017). Pengaruh Kinerja Aparatur Pemerintah Daerah, PengelolaanKeuangan Daerah, Sistem Pengendalian Internal, dan Implementasi Standar Akuntansi Pemerintah Terhadap Penerapan Good Government Governance. JOM Fekon 4 (1), 1859-1872.

Donaldson. Lex, Davis James H. (1991). Stewardship Theory or Agency Theory: CEO Covernance and Shareholders Return. Australian Journal of Management 16 (1): 4965.

Ghozali, Imam. (2013). Aplikasi Analisis Multivariate Dengan Program IBM SPSS 21 (Update PLS Regresi). Semarang: Badan Penerbit Universitas Diponegoro.

Hair Jr, J. F., Black, W. C., Babin, B. J., dan Anderson, R. E. (2009). Multivariate data analysis 7th Edition. Upper Saddle River : Pearson Prentice Hall.

Kamal, Bahri. dan Noermansyah, Asrofi Langgeng. (2015). Analisis Faktor Yang Memengaruhi Implemetasi SIMDA dan Kualitas Laporan Keuangan Pada SKPD. Sustainable Competitive Advantage Journal 5 (1), 1-14. 
LAN. (2000). Akuntabilitas dan Good Government Governance, Modul I. Jakarta: Erlangga.

Mardiasmo. (2002). Akuntansi Sektor Publik, Edisi Kedua. Yogyakarta: Andi.

Mardiasmo. (2009). Akuntansi Sektor Publik, Edisi Keempat. Yogyakarta: Andi.

Oktarina, Mia., K. Raharjo dan R. Andini. 2016. Pengaruh Penerapan Standar Akuntansi Pemerintahan, Kualitas Aparatur Pemerintah Daerah dan Good Governance Terhadap Kualitas Laporan Keuangan di Kota Semarang (Studi Kasus pada Dinas Pengelolaan Keuangan Aset Daerah Kota Semarang Tahun 2014). Journal of Accounting 2 (2), 1-15.

Ole, H.R. (2014). Analisis Implementasi Sistem Informasi Manajemen Daerah (SIMDA) Terhadap Kualitas Laporan Keuangan SKPD (Studi Kasus Pada Dinas PPKAD Kabupaten Minahasa Tenggara). Jurnal Accountability Publisher: Accountability 3 (2), 1-15.

Pulungan, M.S. (2014). Optimalisasi SIMDA dalam Mewujudkan Pengelolaan Keuangan Daerah Kabupaten Kutai Kartanegara Provinsi Kalimantan Timur yang Lebih Berkualitas. Bina Praja Journal, 6 (4), 269-282.

Ramadhan, Asra. dan Rahayu, Sri. (2015). Pengaruh Penerapan Standar Akuntansi, Kualitas Aparatur Terhadap Kualitas Laporan Keuangan (Studi Kasus Pada Biro Keuangan Provinsi Jawa Barat). Jurnal Eproc Telkom University 3(1), 1-7.

Republik Indonesia. (2000). Peraturan Pemerintah Republik Indonesia Nomor 101 tentang Pendidikan dan Pelatihan Jabatan Pegawai Negeri Sipil. Jakarta: Sekretariat Negara.

Republik Indonesia. (2003). Undang-Undang Nomor 17 tentang Keuangan Negara. Jakarta: Sekretariat Negara.

Republik Indonesia. (2004). Undang-Undang Nomor 1 tentang Perbendaharaan Negara. Jakarta: Sekretariat Negara.

Republik Indonesia. (2004a). Undang-Undang Nomor 15 tentang Pemeriksaan Pengelolaan dan Tanggung Jawab Keuangan Negara. Jakarta: Sekretariat Negara.

Republik Indonesia. (2004b). Undang-Undang Nomor 32 tentang Pemerintahan Daerah. Jakarta: Sekretariat Negara.

Republik Indonesia. (2005). Peraturan Pemerintah Nomor 24 tentang Standar Akuntansi Pemerintahan (SAP). Jakarta: Sekretariat Negara.

Republik Indonesia. (2010). Peraturan Pemerintah No 71 tentang Standar Akuntansi Pemerintahan. Jakarta: Sekretariat Negara.

Runtuwene, Christina, David.P.E. Saerang \& J. Morasa. (2017). Pengaruh Penerapan SIMDA, SAP, Motivasi Pegawai dan Kompetensi SDM Terhadap Kualitas Laporan Keuangan Pada Pemerintah Kabupaten. Jurnal Riset Akuntansi dan Auditing Goodwill 8 (2), 299-307.

Sari, Diana. (2013). Pengaruh Sistem Pengendalian Intern Pemerintah, Implementasi Standar Akuntansi Pemerintahan, Penyelesaian Temuan Audit Terhadap Kualitas Laporan Keuangan Pemerintah Daerah dan Implikasinya Terhadap Penerapan Prinsip-Prinsip Tata Kelola Pemerintahan yang Baik (Penelitian Pada Pemerintah Daerah di Provinsi Jawa Barat dan Banten). Indonesian Journal of Economics and Business 1 (10), 166-124. 
Yusniyar., Darwanis \& S. Abdullah. (2016). Pengaruh Penerapan Sistem Akuntansi Pemerintahan dan Pengendalian Intern Terhadap Good Governance dan Dampaknya Pada Kualitas Laporan Keuangan (Studi Pada Skpa Pemerintah Aceh). Jurnal Magister Akuntansi Pascasarjana Universitas Syiah Kuala 5(2), 100-115.

http://www.bpkp.go.id/sakd/konten/333/Versi-2.1.bpkp

http://pemerintah.net/organisasi-perangkat-daerah/

Badan Pengelola Keuangan dan Aset Daerah Provinsi NTB. (2017). Mataram, Nusa Tenggara Barat. 